\title{
Applications of VIKOR Method in Supplier Selection: A Meta-Regression Analysis
}

\author{
Ayşe ANAFARTA iD a Neylan KAYA iD $b$ \\ a Emekli Öğretim Üyesi, Antalya, Türkiye. akanafarta@gmail.com \\ b Akdeniz Üniversitesi, İktisadi ve İdari Bilimler Fakültesi, İşletme Bölümü, Antalya, Türkiye. neylankaya@akdeniz.edu.tr
}

\begin{tabular}{ll}
\hline ARTICLE INFO & ABSTRACT \\
\hline Keywords: & $\begin{array}{l}\text { Purpose - This study attempts to systematically analyze empirical studies using VIKOR method in } \\
\text { solving supplier selection problem and to identify the factors affecting mean S (MS) scores through use of } \\
\text { meta-regression analysis. } \\
\text { VIKOR }\end{array}$ \\
$\begin{array}{l}\text { Fuzzy VIKOR } \\
\text { Integrated VIKOR } \\
\text { Meta-regression analysis }\end{array}$ & $\begin{array}{l}\text { Design/methodology/approach - The sample size of this meta-analysis study consisted of 44 empirical } \\
\text { papers obtained from nine databases and meeting the inclusion criteria. }\end{array}$ \\
$\begin{array}{l}\text { Received 18 June 2021 } \\
\text { Revised 22 August 2021 } \\
\text { Accepted 30 August 2021 }\end{array}$ & $\begin{array}{l}\text { number of decision makers, number of alternatives, number of criteria, country and sector variables did } \\
\text { not affect MS scores. }\end{array}$ \\
$\begin{array}{l}\text { Article Classification: } \\
\text { Research Article }\end{array}$ & $\begin{array}{l}\text { Discussion - Using the fuzzy VIKOR method to solve the supplier selection problem were identified to } \\
\text { provide a lower MS score, while using the integrated VIKOR method ensured a higher MS score. }\end{array}$ \\
& $\begin{array}{l}\text { Detailed studies will provide a better understanding of the relationship between MS scores and the } \\
\text { qualities of studies reporting these scores. }\end{array}$
\end{tabular}

\section{Introduction}

Supplier selection is a significant strategic decision for a firm's supply chain in the current competitive market environment. The right supplier selection plays a significant role in firms as it significantly affects their customers. Since choosing the right suppliers reduces the cost of purchasing and increases competitiveness, the supplier selection process may be considered as the most important action of the purchasing department.

Decision makers regarded the price as the main factor while choosing a supplier in the past years because the firm's main priority was to cut costs. However, today, firms are expected to take into account such factors as quality, price, customer service, talent etc. as a whole in choosing suppliers with a view to taking competitive advantages in the market (Prasad et al., 2017). A good decision making method is of great importance in selecting suppliers. The supplier selection is a complex multi-criteria problem involving not only quantitative but also qualitative factors that can be contradictory and uncertain (Wu \& Liu, 2011). As decision makers do not have sufficient, precise and complete information regarding these factors about suppliers, the supplier selection problem becomes more difficult. A large number of multi-criteria Decision Making (MCDM) techniques such as complex mathematical programming models and simple weighted average were used to solve supplier assessment and selection problems (Ho et al., 2010; Chai et al., 2013).

Recently, the number of researchers using VIse Kriterijumsa Optimizacija I Kompromisno Resenje (VIKOR) and Technique for Order Preference by Similarity to an Ideal Solution (TOPSIS) methods are rapidly increasing in the solution of the supplier selection problem. Using these two methods helps in choosing the best supplier based on different criteria, considering their relative importance (Prasad, 2017). The VIKOR method is known as a convenient and useful decision-making approach that concentrates on selecting from a set of alternatives in the presence of conflicting criteria that may help decision makers make a final decision (Opricovic \& Tzeng, 2004).

One reason for the growing interest in MCDM methods used in supplier selection and an increase in empirical studies is the heterogeneity of the results. The relevant literature holds a large number of studies 
that select the best supplier through use of the VIKOR method (e.g. Bahadori et al., 2017; Sahu et al., 2016; Yücenur \& Demirel, 2012; Huang et. al., 2018), those including other MCDM methods in addition to VIKOR used to compare the obtained results (e.g. Arslan, 2017; You et al., 2015) and studies with integrated methods created using VIKOR with the supplier selection process (e.g. Girubha et al., 2016; Y1lmaz, 2012; Hadian et al., 2019). The versatility in the research results may be influenced not only by the methods but also by the number of criteria used in the selection of suppliers, the number of decision makers, or the application field. This research attempts to conduct a meta-analysis study by examining the publications that use the VIKOR method in order to choose the best supplier. The studies using VIKOR method in supplier selection were searched systematically at first and a meta-regression analysis was carried out with empirical studies selected depending on certain criteria. More specifically, this meta-analysis study aims to examine whether the number of criteria, decision makers, the number of alternatives and individual VIKOR or integrated VIKOR methodologies affect evaluation results.

Supplier evaluation and selection are one of the most significant processes to have an effective supply chain. Building copartnerships that aims to have long working periods in the future with suppliers along with working with fewer trustworthy suppliers may contribute to enhance the value of supply chain. This may result from the fact that the suppliers differ at all stages of the supply chain (Wisner et al., 2008; Ghorabaeea et al., 2017). The purpose of supplier selection processes is to obtain the best supplier for a particular situation. Evaluation and weighing are required to determine which supplier is the "best". The supplier selection process consists of three basic stages in general. The first stage is the determination and selection of the criteria to be considered in the supplier selection. The second stage is the determination of methods for evaluating and ranking suppliers depending upon these criteria. The last stage is the supplier selection according to the evaluation results. Although the majority of the research articles in the relevant field (manufacturing, service etc.) explain how decision criteria are identified, they often focus on the second stage in the supplier selection process (Ristono, 2018). This section includes a literature review regarding the three stages of the supplier selection.

The traditional approach related to supplier selection focuses on selecting suppliers merely on a price basis. However, recently, the number of criteria for supplier selection has increased with the addition of various factors such as social, environmental, political and customer satisfaction concerns to the traditional factors like cost, delivery and quality.

Supplier evaluation and selection decisions are complex as several criteria are required to be taken into account during the decision making process. Numerous scientists and practitioners have focused on the analysis of criteria to measure supplier performance since the 1960s. Dickson identified 23 criteria that were of great importance for supplier selection in 1966. The most important criteria were identified as the supplier's performance history, on-time delivery, the warranty policy and the quality of the product used by the supplier 50 years ago (Simić et al., 2017; Karsak \& Dursun, 2015). Previously, while quantitative criteria were mostly used to evaluate suppliers, qualitative criteria also gained significance after the 1990s. Kar (2014) and Ristono et al. (2018) conducted a systematic literature review related to supplier criteria, and they listed more than 60 general criteria such as past performance, price, geographical distance, product quality, number of errors, on-time delivery, technological capacity, quality management, production capacity, cost, relationship, information technology standards, delivery compatibility, delivery duration, sales force, warranty and proximity, responding to the needs, repairs and services.

The methodological approaches to the supplier selection problem have recently gained importance since supplier selection and evaluation are multi-criteria decision problems that must be solved without any precise information. The purchasing decision process should be modelled and structured in a realistic way in order to solve this problem. In reality, there are various quantitative and qualitative contradictory factors in the supplier selection problem. This problem is often considered as a multi-criteria decision-making problem as various factors have a role in the selection and evaluation of the suppliers. With a view to finding solutions to the supplier selection problem, numerous decision models have been developed by researchers through use of simple mathematical techniques and advanced mathematical programming methods. Ho et al. (2010) made an in-depth analysis of the use of Multi-criteria Decision Making (MCDM) with regard to supplier selection in the research articles conducted between 2000 and 2008. Accordingly, they found that individual approaches (58.97\%) were used slightly more than integrated approaches $(41.03 \%)$. The most 
commonly used individual approach was determined as Data Envelopment Analysis (DEA), which was followed by Analytic Hierarchy Process (AHP), Fuzzy Set Theory, Analytic Network Process (ANP) Simple Multi-Attribute Rating Technique (SMART), Mathematical Programming and Genetic Algorithm (GA).

Having claimed that great improvements regarding supplier selection have occurred in the past five years, Chai et al. (2013) reviewed the literature on the application of decision making methods in supplier selection from 2008 to 2012. The research results revealed that the most frequently used technique was AHP (24.39\%). This was followed by Multi-Objective Optimization (10.57\%), Linear Programming (LP) (15.44\%), ANP $(12.20 \%)$, TOPSIS (14.63\%) and DEA (10.57\%). Chai et al. (2013) also stated that the integrated and hybrid methods, which are formed by combining multiple individual decision making methods, are rapidly increasing in solving supplier selection problems.

Recently, researchers have focused on alternative sorting techniques such as TOPSIS, VIKOR, AHP, ANP, Elimination et Choice Translating Reality (ELECTRE), which are MCDM methods, in order to provide an effective solution to the supplier selection problem. In fact, the number of the studies proposing the hybrid sequencing methodology and technique that combines the classical sequencing methods of MCDM with fuzzy cluster and some other applicable theories or methods is increasing rapidly (Wang \& Cai, 2017) as high flexibility of the ranking method makes a compromised solution more reliable and practical. Both TOPSIS and VIKOR, as typical compromise programming and methods of sorting alternatives, are based on an aggregation function representing closeness function to the ideal points.

Opricovic and Tzeng (2004) stated that the VIKOR method utilizes linear normalization, while TOPSIS method uses vector normalization to eliminate the units of criterion functions. The VIKOR method identifies a compromise solution that is closest to the ideal in the presence of conflict and immeasurable criteria (Hadian, et al., 2019). Opricovic and Tzeng (2004) confronted VIKOR with three MCDM methods like TOPSIS, ELECTRE II and Preference Ranking Organization Method for Enrichment Evaluations (PROMETHEE), and found that the VIKOR results are similar to ELECTRE and PROMETHEE.

The third stage of the supplier selection process is the selection process of the supplier based upon the evaluation results. The VIKOR method is initially presented in the following sections. Then, a meta-analysis is conducted to analyze whether the evaluation results are affected by the number of decision makers, the number of alternatives, by the number of criteria, the industry and country where the application is conducted as well as individual VIKOR and integrated VIKOR methodologies.

The VIseKriterijumska Optimizacija I Kompromisno Resenje (VIKOR) method is an effective tool for sorting out alternatives and finding compromise solutions from a set of alternatives with the aim of helping the decision maker achieve a final solution in the presence of conflicting criteria. Compromise solutions help decision makers determine an acceptable answer for a problem with conflicting criteria. The compromise solution is the feasible one that is closest to the ideal. It compromises means an agreement with mutual privileges (Opricovic \& Tzeng, 2004; Opricovic \& Tzeng, 2007).

The Advantages of VIKOR (Chatterjee et al., 2009):

- The VIKOR method' computational procedure is laborless and presents a systematic as well as a logical approach to have the best decision.

- VIKOR is a method that can be used when a specialist does not know his/her preferences at the beginning of the evaluation.

- The obtained compromise solution may be welcomed by the decision maker since it ensures a maximum group utility of the 'majority' and a minimum individual regret of the 'opponent'.

- The VIKOR results are based on the ideal solution, which is specific to a particular set of alternatives, not the criteria. The inclusion (or exclusion) of an alternative may affect the VIKOR ranking.

Lebesgue criterion (Lp), which is used as aggregation function in computational programming, forms the basis of compromise sequencing for multi-criteria measurement. The VIKOR method starts with the Lpmetric that used an add function. Suppose that suitable alternatives are represented by $A 1, A 2, \ldots, A j, \ldots, A J$. When the performance score of the $A_{j}$ alternative and $i$. criterion are expressed by $f_{i j}, W_{i}$ becomes the weight 
of the criterion (relative importance). Here i refers to $1,2, \ldots, \mathrm{n}$ and $\mathrm{n}$ signifies the number of criteria. The Lpmetric form developed by Duckstein and Opricovic (1980) is formulated as such (Opricovic \& Tzeng, 2004).

$L_{j}^{p}=\left\{\sum_{i=1}^{n}\left[w_{i}\left(\left|f_{i}^{*}-f_{i j}\right|\right) /\left(f_{i}^{*}-f_{i}^{-} \mid\right)\right]^{p}\right\}^{1 / p} \quad 1 \leq p \leq \infty ; j=1,2, \ldots, J$

The VIKOR method uses not only this formula for sequencing measurement, but also (2) for Lp = 1 and (3) for $\mathrm{Lp}=\infty$. The following steps are used in the VIKOR Method.

Step 1: The best $f_{i}^{*}$ and worst $f_{i}^{-}$values are determined for each criterion, $\mathrm{i}=1,2, . ., \mathrm{n}$.

$$
\begin{aligned}
& f_{i}^{*}=\max _{j} f_{i j}, f_{i}^{-}=\min _{j} f_{i j}, \text { if function i shows a gain, } \\
& f_{i}^{*}=\min _{j} f_{i j}, f_{i}^{-}=\max _{j} f_{i j}, \text { if function i refers to cost. }
\end{aligned}
$$

Step 2: $S_{j}$ and $R_{j}$ are calculated for $j=1,2, \ldots, J$.

$$
\begin{aligned}
& S_{j}=L_{i}^{p=1}=\sum_{i=1}^{n} w_{i}\left(f_{i}^{*}-f_{i j}\right) /\left(f_{i}^{*}-f_{i}^{-}\right) \\
& R_{j}=L_{i}^{p=\infty}=\max _{i}\left[w_{i}\left(f_{i}^{*}-f_{i j}\right) /\left(f_{i}^{*}-f_{i}^{-}\right)\right]
\end{aligned}
$$

Here, $w_{i}$ means the criterion weights showing the relative importance. When $\mathrm{p}$ is small (such as $=1$ ), it refers to group benefit, and it emphasizes personal regrets / gaps when $\mathrm{p}$ increases. That is, $\min _{j} L_{j}^{p}$ compromise solution will be preferred as this value is closest to the ideal /desired level. In other words, min Sj means choosing the biggest group benefit, min Rj refer to choosing the smallest among the biggest personal regrets. In fact, the criteria are evaluated as the "benefit" type when the decision maker is concerned with maximization and the "cost" type when it concerns minimization (Ho et al., 2011).

Step 3. $Q_{j}$ values are determined for $j=1,2, \ldots, J$

$Q_{j}=v\left(S_{j}-S^{*}\right) /\left(S^{-}-S^{*}\right)+(1-v)\left(R_{j}-R^{*}\right) /\left(R^{-}-R^{*}\right)$

Here, they are shown as $S^{*}=\min _{j} S_{j}, S^{-}=\max _{j} S_{j}, R^{*}=\min _{j} R_{j}, R^{-}=\max _{j} R_{j}$

The value of $\mathrm{v}$ indicates weighing for the strategy that provides the maximum group benefit.

Step 4: Three order lists are formed by ordering $S, R$ and $Q$ values from small to large.

Step 5: If the following two conditions ( $\mathrm{C} 1$ and $\mathrm{C} 2)$ are provided, $A^{(1)}$ alternative (minimum), the best alternative in the ranking compared to $\mathrm{Q}$ is considered a compromise solution.

\section{C1. Acceptable advantage}

$Q\left(A^{(2)}\right)-Q\left(A^{(1)}\right) \geq D Q$

$D Q=1 /(J-1)$;

Here, $\mathrm{J}$ is the alternative number and $A^{(2)}$ is the second alternative according to $\mathrm{Q}$.

\section{C2. Acceptable stability in decision making}

$A^{(1)}$ alternative should also be in the best order in the $\mathrm{S}$ and/or $\mathrm{R}$ ranking. This means that the compromise solution has acceptable stability in decision making.

If one of these conditions is not met, the set of compromise solutions is presented:

- If only $\mathrm{C} 2$ condition is not met, $A^{(1)}$ ve $A^{(2)}$ alternatives, 
If $\mathrm{C} 1$ condition is not met, $A^{(1)}, A^{(2)}, \ldots, A^{(M)}$ alternatives compose a set of compromise solutions when maximum M value providing $A^{(M)}, Q\left(A^{(2)}\right)-Q\left(A^{(1)}\right) \geq D Q$ relationship is ensured.

$\mathrm{S}=\min \mathrm{S}_{\mathrm{j}}$ in the VIKOR method refers to the maximum group benefit of the compromise solution size. Mean $S_{j}$ (MS) could be considered here as a summary measure which characterises the entire sample for any particular study as $S \mathrm{j}, \mathrm{j}$. represents the closeness of the alternative to the ideal solution and is usually reported in each study.

\section{Method}

A six-step process was followed for systematic literature review (Figure 1). Step (i) consists of selecting nine databases containing the vast majority of the relevant scientific journals: SCOPUS, EBSCO, Emerald, Springer-link Journals, WOS, Science Direct, IEEE Xplore, ULAKBIM and DERGIPARK databases were used for searching articles. Step (ii) includes defining the keywords for the search: The keywords such as "VIKOR" and "supplier selection" were used. The search was limited to the title, keywords and abstract of the full text articles. All studies published in 2019 and before have been scanned. The search was finalized with 221 papers. The limitation of this study is that the data of the study covers the year 2019 and before. Inclusion criteria were identified for meta-analysis in Step (iii).

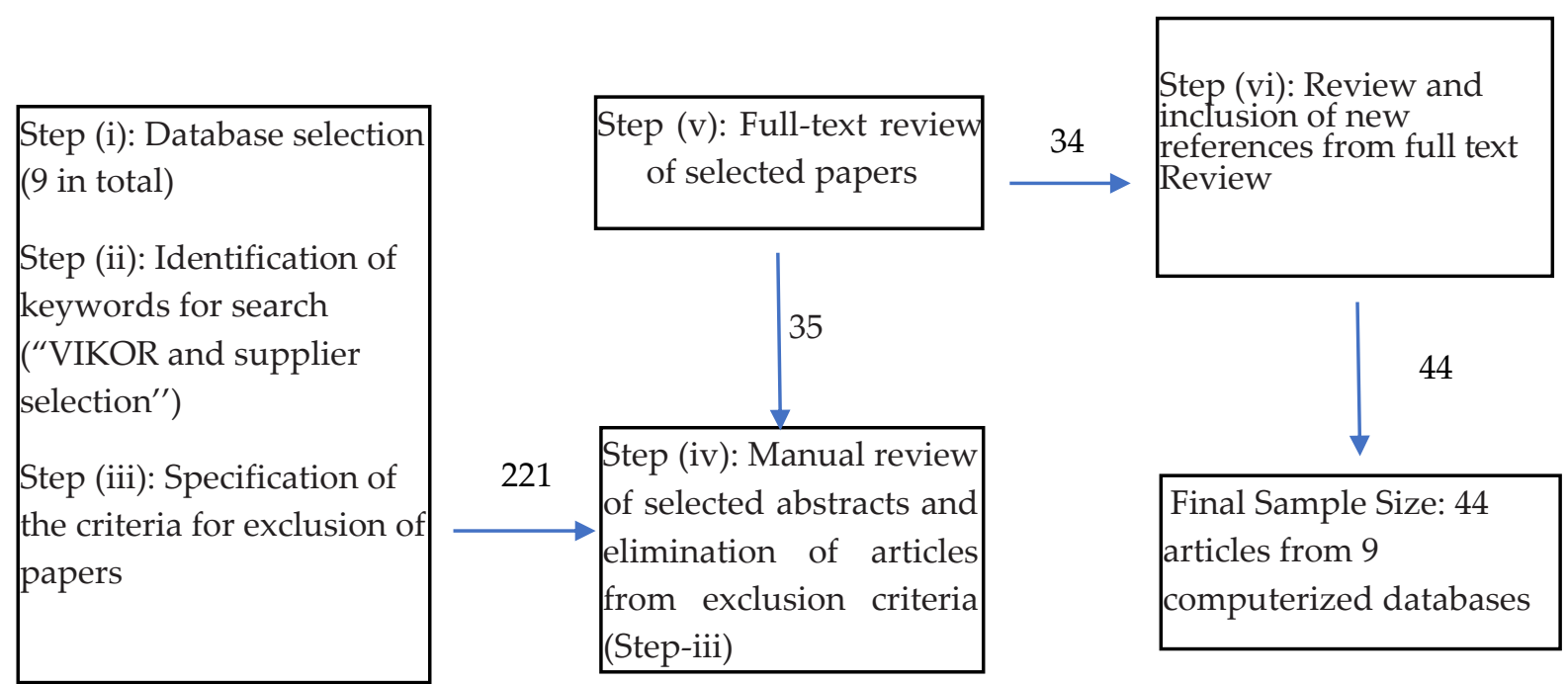

Figure 1. Sample Selection Process

Implementation based studies using VIKOR method for supplier selection problem were included in metaregression analysis. Such papers that are theoretical or try to explain the VIKOR method using a hypothetical example and those with missing data were not included in the study. Step (iv) included a manual review related to the abstracts regarding the remaining 221 articles by implementing the exclusion criteria of Step (iii). All abstracts were read by two researchers. Besides, papers available in more than one database were eliminated. Thus, 35 articles were obtained for full text analysis. The review process was interactive and led to a high level of agreement. After the full text review in Step (v), the number of studies decreased in 34. In Step (vi), 10 new articles were added based on manual searches on articles from Step (v). The final sample size included 44 empirical articles.

A meta-regression analysis was implemented to the distributions from the sample of 44 papers. Metaregression analysis (MRA) is a statistical method used for gathering and combining results from individual studies to assess the extent to which the characteristics of each study (number of decision makers, number of criteria, number of alternatives, the country of application, an individual or integrated method etc.) affect the findings. In a meta-regression model, the differences between studies are used as explanatory variables. MS was used as the dependent variable in the present study. MS scores are between [0; 1], so they are censored data. Therefore, this study employed the Tobit regression model as a censored regression model. 


\subsection{Empirical Model}

MS levels obtained from the elicited data are used as dependent variables in the Tobit model. Censoring of the dependent variable is prevalent in microeconomic data. When the dependent variable is censored, values in a certain range are all transformed to (or reported as) a single value (Greene, 2008). The Tobit Model, an extension of the Probit model, was developed by James Tobin (Tobin, 1958; Gujarati, 2004). In other words, we use Tobit model when there is censoring from below and above (Maddala, 1989).

Model I: MS=f (NC, NA, NDM, FUZZY, ASIANC)

where MS is the mean Sj (Eq. 2), as reported in the studies. NC, NA and NDM represent the number of decision makers, the number of alternatives and the number of criteria respectively. FUZZY is a dummy variable, it takes 1 or 0 if the VIKOR method used in the analysis is Fuzzy VIKOR. Upon analyzing the studies in the meta-analysis pool, Fuzzy VIKOR was identified to be used together with either individual or integrated methods. The FUZZY dummy variable in Model I and Model III takes the value 1 when fuzzy VIKOR is used in both individual and integrated models. ASIANC is a dummy variable equal to 1 for Asian countries and 0 otherwise.

\section{Model II: MS=f (NC, NA, NDM, ASIANC, INTEGRATED)}

where INTEGRATED is a dummy variable, if the VIKOR method used in the analysis is integrated with other methods, it gets 1 ; if not it takes the value 0 . All other variables are as defined in (5) above.

Model III: MS=f (NC, NA, NDM, FUZZY, ASIANC, SECTOR)

where SECTOR is a dummy variable, if it is a manufacturing sector, it takes the value of 1 and if it is a service sector, it takes the value of 0 . All other variables are as defined in (5) above.

\section{Results}

\subsection{Study descriptors}

Table 1 depicts all the articles' author names, publication year, country, number of criteria, number of alternatives, number of decision makers, individual or integrated method information of the VIKOR and sector information. Table 1 also suggests that 44 empirical studies in the systematic review study were conducted between 2008-2019. There were no such studies conducted before 2008 that met the inclusion criteria. In parallel to the relevant literature, the number of the empirical studies using VIKOR method in supplier selection were found to increase. While the number of applied publications made until 2010 was 8 , this number increased to 36 after 2010. Upon examining the relevant literature, the empirical studies using VIKOR method have become common after the study "Extended VIKOR Method in Comparison with Outranking Methods. European Journal of Operational Research 178: 514-529." was carried out by Opricovic and Tzeng (2007).

More than half of the studies available in the meta-analysis pool used the Fuzzy VIKOR method with the aim of solving the supplier selection problem. 30 studies were determined to integrate other MCDM methods such as DEMATEL, ELECTRE, ANP, AHP, fuzzy ANP, fuzzy AHP, SWARA into the VIKOR method. The systematic review study evaluated whether an alternative method to the VIKOR method was utilized for solving the supplier selection problem and whether the results were consistent with one another. In 8 out of 44 studies, one of the MCDM methods such as AHP, ELECTRE and TOPSIS were used for comparison purposes, and similar results were obtained in 7 papers. 
A. Anafarta - N. Kaya 13/3 (2021) 2523-2536

Table 1. Overview of the empirical studies

\begin{tabular}{|c|c|c|c|c|c|c|}
\hline $\begin{array}{c}\text { Author (s) and } \\
\text { Year }\end{array}$ & Country & $\begin{array}{l}\text { Technique and } \\
\text { Approach }\end{array}$ & $\begin{array}{c}\text { Number of } \\
\text { Decision } \\
\text { Maker } \\
\end{array}$ & $\begin{array}{l}\text { Number of } \\
\text { Alternative }\end{array}$ & $\begin{array}{c}\text { Number } \\
\text { of } \\
\text { Criteria }\end{array}$ & Sector \\
\hline Dai et al., 2008 & China & Fuzy VIKOR & 1 & 4 & 4 & Service \\
\hline $\begin{array}{l}\text { Guo \& Zhang, } \\
2008\end{array}$ & China & $\begin{array}{l}\text { VIKOR and Rough } \\
\text { Set Theory }\end{array}$ & 1 & 5 & 4 & Manufacturing \\
\hline $\begin{array}{l}\text { Huang et al., } \\
2008\end{array}$ & China & $\begin{array}{l}\text { VIKOR and } \\
\text { Entropy }\end{array}$ & 1 & 5 & 7 & Manufacturing \\
\hline $\begin{array}{l}\text { Jianchang et al., } \\
2008\end{array}$ & China & $\begin{array}{l}\text { VIKOR and Rough } \\
\text { Set Theory }\end{array}$ & 1 & 3 & 5 & Manufacturing \\
\hline $\begin{array}{l}\text { Lihong et al., } \\
2008\end{array}$ & China & $\begin{array}{l}\text { VIKOR, AHP and } \\
\text { Entropi }\end{array}$ & 1 & 4 & 8 & Service \\
\hline Liu \& Du, 2008 & China & VIKOR and AHP & 3 & 4 & 10 & Service \\
\hline $\begin{array}{l}\text { Chen \& Wang, } \\
2009\end{array}$ & Taiwan & Fuzy VIKOR & 5 & 5 & 10 & Manufacturing \\
\hline $\begin{array}{l}\text { Sanayei et al., } \\
2010\end{array}$ & USA & Fuzy VIKOR & 3 & 5 & 5 & Manufacturing \\
\hline $\begin{array}{l}\text { Amiri et al., } \\
2011\end{array}$ & Iran & Fuzzy VIKOR & 3 & 5 & 15 & Manufacturing \\
\hline $\begin{array}{l}\text { Göktürk et al., } \\
2011\end{array}$ & Turkey & VIKOR and ANP & 1 & 14 & 11 & Manufacturing \\
\hline $\begin{array}{l}\text { Shemshadi et } \\
\text { al., } 2011\end{array}$ & Iran & $\begin{array}{l}\text { Fuzzy VIKOR and } \\
\text { Shannon Entropy }\end{array}$ & 3 & 4 & 5 & Manufacturing \\
\hline $\begin{array}{l}\text { Sanayei et al., } \\
2011\end{array}$ & USA & Fuzy VIKOR & 3 & 4 & 5 & Manufacturing \\
\hline $\begin{array}{l}\text { Yucenur } \\
\text { \&Demirel, } 2012\end{array}$ & Turkey & Fuzzy VIKOR & 3 & 4 & 8 & Service \\
\hline Akyüz, 2012 & Turkey & Fuzzy VIKOR & 5 & 5 & 7 & Service \\
\hline $\begin{array}{l}\text { Roostaee et al., } \\
2012\end{array}$ & Iran & Fuzzy VIKOR & 3 & 5 & 5 & Manufacturing \\
\hline $\begin{array}{l}\text { Samantra et al., } \\
2012\end{array}$ & India & Fuzzy VIKOR & 3 & 5 & 6 & Manufacturing \\
\hline $\begin{array}{l}\text { Mirahmadi \& } \\
\text { Teimoury, } 2012 \\
\end{array}$ & Iran & Fuzzy VIKOR & 3 & 4 & 14 & Manufacturing \\
\hline Y1lmaz, 2012 & Turkey & VIKOR and AHP & 3 & 4 & 8 & Manufacturing \\
\hline $\begin{array}{l}\text { Tayyar \& } \\
\text { Arslan, } 2013\end{array}$ & Turkey & VIKOR and AHP & 4 & 4 & 18 & Manufacturing \\
\hline $\begin{array}{l}\text { Wu \& Geng, } \\
2014\end{array}$ & China & Fuzzy VIKOR & 4 & 6 & 13 & Service \\
\hline Hsu et al., 2014 & Taiwan & $\begin{array}{l}\text { VIKOR, DEMATEL } \\
\text { and Fuzzy ANP }\end{array}$ & 3 & 5 & 10 & Service \\
\hline $\begin{array}{l}\text { Geng \& Liu, } \\
2015\end{array}$ & China & VIKOR & 8 & 6 & 10 & Manufacturing \\
\hline You et al., 2015 & China & $\begin{array}{l}\text { VIKOR and } \\
\text { interval 2-tuple } \\
\text { linguistic }\end{array}$ & 4 & 5 & 4 & Service \\
\hline Kuo et al., 2015 & Taiwan & $\begin{array}{l}\text { VIKOR, DEMATEL } \\
\text { and ANP }\end{array}$ & 2 & 5 & 17 & Manufacturing \\
\hline Ar, et al., 2015 & Turkey & $\begin{array}{l}\text { VIKOR, DEMATEL } \\
\text { and ANP }\end{array}$ & 10 & 3 & 17 & Manufacturing \\
\hline Kara \& Ecer, & Turkey & VIKOR and AHP & 4 & 5 & 12 & Manufacturing \\
\hline
\end{tabular}


A. Anafarta - N. Kaya 13/3 (2021) 2523-2536

\begin{tabular}{|c|c|c|c|c|c|c|}
\hline 2016 & & & & & & \\
\hline $\begin{array}{ll}\text { Awasthi } & \& \\
\text { Kannan, } 2016 & \end{array}$ & Canada & Fuzzy VIKOR & 3 & 3 & 16 & Manufacturing \\
\hline $\begin{array}{l}\text { Prasad et al., } \\
2017\end{array}$ & India & VIKOR & 10 & 5 & 5 & Manufacturing \\
\hline $\begin{array}{l}\text { Bahadori et al., } \\
2017\end{array}$ & Iran & Fuzzy VIKOR & 3 & 6 & 6 & Service \\
\hline Zhou \&Xu, 2017 & China & $\begin{array}{l}\text { Fuzzy VIKOR, } \\
\text { DEMATEL and } \\
\text { ANP }\end{array}$ & 6 & 4 & 8 & Manufacturing \\
\hline $\begin{array}{l}\text { Wang \&Cai, } \\
2017\end{array}$ & China & VIKOR & 4 & 6 & 4 & Service \\
\hline Arslan, 2017 & Turkey & VIKOR and AHP & 3 & 3 & 4 & Manufacturing \\
\hline $\begin{array}{l}\text { Saraçoğlu \& } \\
\text { Dağıstanlı, } 2017\end{array}$ & Turkey & VIKOR and AHP & 1 & 12 & 19 & Service \\
\hline Wu, et al., 2017 & China & Fuzzy VIKOR & 13 & 4 & 10 & Manufacturing \\
\hline $\begin{array}{l}\text { Luthra et al., } \\
2017\end{array}$ & India & VIKOR and AHP & 5 & 5 & 22 & Manufacturing \\
\hline $\begin{array}{l}\text { Awasthi et al., } \\
2018\end{array}$ & Canada & $\begin{array}{l}\text { Fuzzy VIKOR and } \\
\text { Fuzzy AHP }\end{array}$ & 3 & 3 & 25 & Manufacturing \\
\hline $\begin{array}{l}\text { Demir et al., } \\
2018\end{array}$ & Turkey & VIKORSORT & 1 & 20 & 10 & Service \\
\hline $\begin{array}{l}\text { Banaeian et al., } \\
2018\end{array}$ & Iran & Fuzzy VIKOR & 3 & 4 & 4 & Manufacturing \\
\hline $\begin{array}{l}\text { Hadian et al., } \\
2019\end{array}$ & Iran & VIKOR and AHP & 6 & 6 & 11 & Service \\
\hline Azizi et al., 2019 & Iran & VIKOR and BWM & 8 & 15 & 9 & Manufacturing \\
\hline
\end{tabular}

Research findings also suggested that the number of criteria used in supplier selection varied between 4 and 25. Although it varies across the sectors, various criteria such as quality, price, technical capacity, payment terms, packaging and transporting quality, flexibility, timely delivery, speed, leannes, the supplier's background, the possibility of long-term cooperation, geolocation, technology, environmental performance, green technology, agility in operating systems, logistics agility, distribution network quality are used. The number of decision makers used in supplier selection differed between 1 and 13. Table 1 displays that the number of decision makers was three in $43.2 \%$ of the studies in the systematic review pool. The number of alternatives in the studies varied between 3 and 20. The number of alternative suppliers was concentrated in 4 and 5 suppliers. The studies on the VIKOR method were identified to be mostly conducted in Asian countries. The majority of 44 empirical studies using VIKOR method in supplier selection were carried out in Taiwan, Iran, China, India and Turkey. Besides, $70.5 \%$ of the applications in the studies belonged to the manufacturing sector.

\subsection{Meta-Regression Analysis}

Meta-regression analysis was used to explain the heterogeneity in the results of studies included in the metaanalysis. Table 2 depicts the econometrics results for Models I-III using Tobit approach. The compromise solutions in the VIKOR method are the closest suitable solutions to the ideal solution (Opricovic \& Tzeng, 2004). Since MS values are a measure of proximity to the ideal point, they were taken as a dependent variable during meta-regression analysis and independent variables affecting MS value were analyzed. 
A. Anafarta - N. Kaya 13/3 (2021) 2523-2536

Table 2. Tobit analysis results of MS

\begin{tabular}{|l|cc|cc|cc|}
\hline \multirow{2}{*}{ Variables } & \multicolumn{2}{|c|}{ Model I } & \multicolumn{2}{c|}{ Model II } & \multicolumn{2}{c|}{ Model III } \\
& Coef. & P-value & Coef. & P-value & Coef. & P-value \\
\hline CONSTANT & 6.103 & $0.000^{* * *}$ & 4.374 & & 5.423 & $0.000^{* * *}$ \\
& & & $0.000^{* * *}$ & & & \\
\hline NC & -0.037 & 0.371 & -0.019 & 0.630 & -0.033 & 0.422 \\
\hline NA & -0.006 & 0.916 & -0.002 & 0.970 & 0.020 & 0.755 \\
\hline NDM & 0.076 & 0.364 & 0.064 & 0.442 & 0.056 & 0.511 \\
\hline FUZZY & -0.947 & $0.038^{* *}$ & & & -0.866 & $0.058^{*}$ \\
\hline ASIANC & -1.104 & 0.355 & -0.558 & 0.628 & -0.871 & 0.466 \\
\hline INTEGRATED & & & 0.950 & $0.044^{* *}$ & & \\
\hline SECTOR & & & & & 0.535 & 0.275 \\
\hline Log likelihood & -77.559 & & -77.659 & & -76.972 & \\
\hline S.E. of regresssion & 1.537 & & 1.541 & & 1.538 & \\
\hline
\end{tabular}

${ }^{*} \mathrm{p}<0.10{ }^{* *} \mathrm{p}<0.05 \quad{ }^{* * *} \mathrm{p}<0.01$

Table 2 indicates that the parameter estimates of NC, NA and NDM variables were statistically significant in all three models, meaning that the compromise solution was not affected by the number of decision makers, number of alternatives and number of criteria used in supplier selection. The regression coefficient for FUZZY was statistically significant ( $\mathrm{p}<0.05$ for Model I and $\mathrm{p}<0.1$ for Model III) and negative. FUZZY is a dummy variable and if the FUZZY coefficient is negative, it means that the compromise solution will be closer to the ideal solution in the presence that the VIKOR method used to solve the supplier selection is fuzzy VIKOR. The parameter estimation of the INTEGRATED dummy variable in Model II was found to be statistically significant and positive $(\mathrm{p}<0.05)$. This indicates that if another method is used as a complement with the VIKOR method in supplier selection, the compromise solution will move away from the ideal solution. The parameter estimates for the dummy variables ASIANC and SECTOR were not statistically significant. MS value was not affected by the country or sector in which the study was conducted.

\section{Discussions}

Supplier selection and performance evaluation are strategically significant for companies due to mass customization, global competition, challenging economic conditions and high customer expectations. Considering the relevant literature, MCDM methods have a key role in the solution of supplier selection problem in recent years. TOPSIS, AHP and ANP methods or their fuzzy extensions were the mostly used MCDM methods in review studies regarding supplier selection (Ho et al., 2010; Chai et al., 2013; Simić et al., 2017). Besides, the researchers such as Gul et al. (2016) and Mardani et al (2016) having carried out a comprehensive systematic review of the VIKOR method stated that VIKOR-related studies have recently gained popularity in various MCDM problems due to their ability to compromise ranking performance by comparing the measure of proximity to the ideal solution. This study systematically examined the empirical studies using the VIKOR method in solving the supplier selection problem without year limitation and determined the variables affecting the MS scores used in the supplier selection through meta-regression analysis.

The Tobit analysis results (Model I and Model III) revealed that the fuzzy VIKOR approach led to lower MS predictions. The decrease in MS value showed that the distance of the compromise solution to the ideal solution is reduced when the fuzzy VIKOR method is used to solve the supplier selection problem, which refers to a better compromise solution. Many researchers recommend using fuzzy set theory and especially fuzzy multi-criteria decision making models to model uncertainty in supplier selection situations. Simić et al. (2016) examined how fuzzy cluster theory, hybrid solutions and fuzzy decision making can be used in various supplier evaluation and selection models over a 50-year period. In this review study, Simić et al. (2016) drew attention to the potential benefits of fuzzy models used in supplier evaluation and selection to reduce the uncertainty and risks of the global world business environment. Ghorabaee et al. (2017) identified the most common multi-attribute decision making (MADM) approaches for fuzzy evaluation and supplier selection by examining 339 publications, including some book chapters and conferences between 2001-2016. 
The systematic review results of the studies available in the meta-analysis pool showed that VIKOR, Fuzzy VIKOR and integrated VIKOR methods have increased (68.2\%) over the years in terms of solving supplier selection problems. However, Model II (Table 2) depicts a positive relationship between the INTEGRATED dummy variable and MS. This paved the way for the fact that a larger MS score will be obtained if an integrated VIKOR method is used instead of individual VIKOR in solving the supplier selection problem. Considering the papers in the meta-analysis pool, AHP and VIKOR (Kara \& Ecer, 2016; Arslan, 2017; Lutuhra et al., 2017), fuzzy VIKOR and fuzzy AHP (Yılmaz, 2012; Saraçoğlu \& Dagestanli, 2017), VIKOR and ANP (Göktürk et al., 2011), , fuzzy ANP and DEMATEL (DANP) and VIKOR (Hsu et al., 2014; Kuo et al., 2015) methods were integrated. Table 2 also clarified that the number of decision makers, number of alternatives, number of criteria, the country and sector did not affect MS estimates in three models.

Another significant research finding revealed that MCDM methods such as ELECTRE, AHP and TOPSIS, which are used for comparison with the VIKOR method, had the same results for the supplier selection problem. For instance, Girubha et. get. (2016) compared ISM-ANP-VIKOR and ISM-ANP-ELECTRE integrated methods and found similar results for the solution of sustainable supplier selection problem. Arslan (2017), who compared AHP and VIKOR methods, reached the same compromise solution. In their studies, Tayyar and Arslan (2013) compared TOPSIS and VIKOR methods and obtained the same ranking. Banaeian et al. (2018) showed that fuzzy VIKOR, fuzzy GRA and fuzzy TOPSIS methods reached the same supplier rankings in solving the green supplier selection problem.

\section{Conclusions}

This research represents the first attempt to use meta-analysis in order to examine MS estimates. The research analyzed whether the number of criteria, number of decision makers number of alternatives, type of VIKOR method (individual, fuzzy or integrated), the country and sector variables affected MS scores by examining the data obtained from 44 published empirical articles using the VIKOR method in order to solve the supplier selection problem. Meta-regression was used during data analysis.

This research is paramount in terms of showing that using fuzzy VIKOR method rather than traditional VIKOR method will give a better result to solve the supplier selection problem. It is likely that the use of the fuzzy VIKOR method in supplier selection leads to the emergence of a suitable solution closer to the ideal solution. On the other, the fact that meta-regression findings (Model II) showed that the ideal solution is removed when the integrated VIKOR method is used reveals the need for a more detailed study with a larger sample size in the further studies. Because the number of new methods in which two or more MCDM methods are integrated in the solution of supplier selection problems is increasing day by day.

The second significant point is that other MCDM methods used for comparison with VIKOR results give similar results as a result of the systematic review. However, this finding should be interpreted with full of care since there are a limited number of comparing articles (only eight articles). As empirical papers making method comparisons in the future increase, the studies similar to this may increase.

The third significant point is that MS scores did not vary across the number of decision makers, the number of alternatives, the number of criteria, the country and the sector, showing that VIKOR method can be used effectively as an alternative to the other MCDM methods in solving supplier selection problems.

As a result, there is a need to better understand the main determinants of MS estimates in order to find a better solution to the supplier selection problem. Detailed studies will provide a better understanding of the relationship between MS scores and the qualities of the studies reporting these scores. 


\section{References}

Akyüz, G. (2012). Supplier selection with VIKOR method. Atatürk University Journal of Economics and Administrative Sciences, 26 (1), 197-214.

Amiri, M., Ayazi, S. A., Olfat, L. \& Moradi, J. S. (2011). Group decision making process for supplier selection with VIKOR under fuzzy circumstance case study: An Iranian car parts supplier. International Bulletin of Business Administration, 10, 62-75.

Ar, İ. M., Gökşen, H. \& Tuncer, M. A. (2015). Using integrated DEMATEL-ANP-VIKOR method for supplier selection in cable sector. Ege Academic Review, 5 (2), 285-300.

Arslan, H. M., (2017). Election of the best supplier with the AHP-VIKOR method and an application. Electronic Journal of Social Sciences, 16(63), 1203-1217.

Awasthi, A., Govindan, K. \& Gold, S. (2018). Multi-tier sustainable global supplier selection using a fuzzy AHP-VIKOR based approach. International Journal of Production Economics, 195, 106-117.

Awasthi, A. \& Govindan, K. (2016). Green supplier development program selection using NGT and VIKOR under fuzzy environment. Computers $\mathcal{E}$ Industrial Engineering, 91, 100-108.

Azizi, E., Javanshir, H., Jafari, D. \& Ebrahimnejad, S. (2019). Presenting an integrated BWM-VIKOR-based approach for selecting suppliers of raw materials in the supply chain with emphasis on agility and exibility criteria (Case study: Saipa corporation). Scientia Iranica E, 26(4), 2601-2614.

Bahadori, M., Hosseinia, S. M., Teymourzadeha, E., Ravangardb, R., Raadabadic, M. \& Alimohammadzadeh, K. (2017). A supplier selection model for hospitals using a combination of artificial neural network and fuzzy VIKOR. International Journal Of Healthcare Management.

Banaeian, N., Mobli, H., Fahimnia, B. Nielsen, I. E. \& Omid, M. (2018). Green supplier selection using fuzzy group decision making methods: a case study from the agri-food industry. Computers and Operations Research, 89, 337-347.

Calı, S. \& Balaman, S. Y. (2019). A novel outranking based multi criteria group decision making methodology integrating ELECTRE and VIKOR under intuitionistic fuzzy environment. Expert Systems with Applications, 119 (1), 36-50.

Chai, J., Liu, J. N. K. \& Ngai, E. W. T. (2013). Application of decision-making techniques in supplier selection: A systematic review of literature. Expert Systems with Applications, 40 (10), 3872-3885.

Chatterjee, P., Athawale, V. M. \& Chakraborty, S. (2009). Selection of materials using compromise ranking and outranking methods. Materials and Design, 30 (10), 4043-4053.

Chen, L. Y. \& Wang, T. (2009). Optimizing partners' choice in IS/IT outsourcing projects: The strategic decision of fuzzy VIKOR. International Journal of Production Economics, 120 (1), 233-242.

Dai, L., Liu, Y. \& Zhang, Z. (2008). Supplier selection with multiple criteria under fuzzy environment. International Conference on Wireless Communications, Networking and Mobile Computing, China, 12-17 October 2008, IEEE, 1-4.

Demir, L., Akpınar, M. E., Araz, C. \& Ilgin, M. A. (2018). A green supplier evaluation system based on a new multi-criteria sorting method: VIKORSORT. Expert Systems with Applications, 114, 479-487.

Dickson, G. W. (1966). An analysis of vendor selection system and decisions. Journal of Purchasing, 2 (1), 5-17.

Geng, X. \& Liu, Q. (2015). A hybrid service supplier selection approach based on variable precision rough set and VIKOR for developing product service system. International Journal of Computer Integrated Manufacturing, 28 (10), 1063-1076.

Ghorabaeea, M. K., Amiria, M., Zavadskasb, E. K. \& Antuchevicieneb, J. (2017). Supplier evaluation and selection in fuzzy environments: a review of MADM approaches. Economic Research-Ekonomska Istraživanja, 30 (1), 1073-1118. 
A. Anafarta - N. Kaya 13/3 (2021) 2523-2536

Girubha, J., Vinodh, S. \& Kek, V. (2016). Application of interpretative structural modelling integrated multi criteria decision making methods for sustainable supplier selection. Journal of Modelling in Management, 11(2), 358-388

Göktürk, İ. F., Eryılmaz, A. Y., Yörür, B. \& Yuluğkural, Y. (2011). Usage of ANP and VIKOR methods for supplier assessment and selection problem of a company. DPÜ Journal of Institute of Science, 25, 61-74.

Greene, W. H. (2008). Econometric analysis. 6th ed. Pearson Prentice Hall, New Jersey.

Gujarati, D. N. (2004). Basic econometrics, 4th ed. McGraw-Hill, New York.

Gul, M., Celik, E., Aydin, N., Gumus, A. T. \& Guneri, A. F. (2016). A state of the art literature review of VIKOR and its fuzzy extensions on applications. Applied Soft Computing, 46, 60-89.

Guo, J. \& Zhang, W. (2008). Selection of suppliers based on rough set theory and VIKOR algorithm. International Symposium on Intelligent Information Technology Application Workshops, China, 21-22 December, IEEE, 49-52.

Jianchang, L., Zhiwei, Z. \& Lin, Z. (2008). Evaluation and selection of suppliers in supply chain based on RST and VIKOR algorithm. Chinese Control and Decision Conference, China, 2-4 July 2008, IEEE, 1913-1916.

Hadian, H. S., Chahardolib, B., Golmohammadic, A-M. \& Mostafaeipourc, A. (2019). A practical framework for supplier selection decisions with an application to the automotive sector. International Journal of Production Research.

Ho, W., Xu, X. \& Dey, P. K. (2010). Multi-criteria decision making approaches for supplier evaluation and selection: A literature review. European Journal of Operational Research, 202, 16-24.

Ho, W-R., Tsai, C-L., Tzeng G-H. \& Fang, S-K. (2011). Combined DEMATEL technique with a novel MCDM model for exploring portfolio selection based on CAPM. Expert Systems with Applications, 38, 16-25.

Hsu, C-W., Kuo, T-C., Shyu, G-S. \& Chen, P-S. (2014). Low carbon supplier selection in the hotel industry. Sustainability, 6, 2658-2684.

Huang, Y., Yan, Y. \& Ji, Y. (2008). Optimization of Supply Chain Partner Based on VIKOR Method and G1 Method. International Seminar on Future BioMedical Information Engineering, China, 18 December 2008, IEEE, 172-175.

Kar, A. K. (2014). Exploring the importance of different supplier selection criteria. Management Research Review. 37(1), 89-105.

Kara, I. \& Ecer, F. (2016). Supplier selection with AHP-VIKOR integrated method: textile industry application). Journal of Social Sciences Institute, 18(2), 255-272.

Karsak, E. \& Dursun, M. (2015). An integrated fuzzy MCDM approach for supplier evaluation and selection. Computers \& Industrial Engineering, 82, 82-93.

Kuo, T.C., Hsu, C- W. \& Li, J-Y. (2015). Developing a green supplier selection model by using the DANP with VIKOR. Sustainability, 7, 1661-1689.

Lihong, M. Yanping, Z. \& Zhiwei, Z. (2008). Improved VIKOR Algorithm Based on AHP and Shannon Entropy in the Selection of Thermal Power Enterprise's Coal Suppliers. International Conference on Information Management, in Innovation Management and Industrial Engineering, United States, 19-21 December 2008, IEEE, 129-133.

Liu, P. \& Du, H. (2008). The research of supplier selection based on hybrid decision-making index and VIKOR Method, International Symposium on Electronic Commerce and Security, China, 3-5 August 2008, IEEE, 661-664.

Luthra, S., Govindan, K., Kannan, D., Mangla, S. K. \& Garg, C. P. (2017). An integrated framework for sustainable supplier selection and evaluation in supply chains. Journal of Cleaner Production, 140, 1686-1698.

Maddala, G. S. (1989). Introduction to Econometrics, Macmillan Publishing Company, New York. 
Mardani, A., Zavadskas, E. K., Govindan, Senin, A. A. \& Jusoh, A. (2016). VIKOR Technique: a systematic review of the state of the art literature on methodologies and applications. Sustainability, 8, 1-37.

Meksavang, P., Shi, H., Lin, S-M. \& Liu, H-C. (2019). An extended picture fuzzy VIKOR approach for sustainable supplier management and its application in the beef industry. Symmetry, 11, 468-487.

Mirahmadi, N. \& Teimoury, I. (2012). A fuzzy VIKOR model for supplier selection and evaluation: case of EMERSUN Company, Journal of Basic Applied Scientific Research, 2(5), 5272-5287.

Opricovic, S. \& Tzeng, G-H. (2004). Compromise solution by MCDM methods: a comparative analysis of VIKOR and TOPSIS. European Journal of Operational Research, 156, 445-455.

Opricovic, S. \& Tzeng, G-H. (2007). Extended VIKOR Method in comparison with outranking methods. European Journal of Operational Research, 178: 514-529.

Prasad, K. G. D., Prasad, M. V., Kumar, R. S., Prasad, V. S. D. \& Shanmukhi, K. V. S. J. (2017). Kano-based VIKOR Decision model for Supplier Selection - A Case Study. International Journal of Mechanical Engineering (SSRG-IJME) - Special Issue, 227-231.

Ristono, A., Pratikto, Budi Santoso, P. \& Pambudi Tama, I. (2018). A literature review of design of criteria for supplier selection. Journal of Industrial Engineering and Management, 11(4), 680-696.

Roostaee, R., Izadikhah, M., Lotfi, F. H. \& Malkhalifeh, F. R. (2012). A multi-criteria intuitionistic fuzzy group decision making method for supplier selection with VIKOR method. International Journal of Fuzzy System Applications, 2(1), 1-17.

Sahu, A. K., Datta, S. \& Mahapatra, S. S. (2016). Evaluation and selection of resilient suppliers in fuzzy environment: exploration of fuzzy-VIKOR. Benchmarking: An International Journal, 23 (3), 651-673.

Samantra, C., Datta, S. \& Mahapatra, S. S. (2012). Application of fuzzy based VIKOR approach for multiattribute group decision making (MAGDM): A case study in supplier selection. Decision Making in Manufacturing and Services, 6 (1), 25-39.

Sanayei, A., Farid Mousavi, S. \& Yazdankhah, A. (2010). Group decision making process for supplier selection with VIKOR under fuzzy environment. Expert Systems with Applications, 37(1), 24-30.

Saraçoğlu, İ. \& Dağıstanlı, H., A. (2017). Application of FUZZY-AHP and VIKOR methods for supplier selection in an interconnect company. Journal of Yaşar University, 12 (Special Issue), 40-54.

Shemshadi, A., Shirazi, H., Toreihi, M. \& Tarokh, M. J. (2011). A fuzzy VIKOR method for supplier selection based on entropy measure for objective weighting. Expert Systems with Applications, 38 (10), 1216012167.

Simić, D., Kovačević, I., Svirčević, V. \& Simić, S. (2017). 50 years of fuzzy set theory and models for supplier assessment and selection: A literature review. Journal of Applied Logic, 24, 85-96.

Tayyar, N. \& Arslan, P. (2013). Selection of the best sub-contractor in clothing sector using AHP and VIKOR methods. Journal of Social Sciences, 1(1), 340-358.

Tobin, J. (1958). Estimation of Relationships for Limited Dependent Variables. Econometrica, 26(1), 24-36.

Wang, X. \& Cai, J. (2017). A group decision-making model based on distance-based VIKOR with incomplete heterogeneous information and its application to emergency supplier selection. Kybernetes, 46(3), 501-529.

Wisner, J., Tan, K. C., \& Leong, G. (2008). Principles of supply chain management. Boston, MA: Cengage Learning.

Wu, M. \& Liu, Z. (2011). The supplier selection application based on two methods: VIKOR algorithm with entropy method and Fuzzy TOPSIS with vague sets method. International Journal of Management Science and Engineering Management, 6(2), 109-115.

Wu, T-H., Chen, C-H., Mao, N. \& Lu, S-T. (2017). Fishmeal supplier evaluation and selection for aquaculture enterprise sustainability with a fuzzy MCDM approach. Symmetry, 9, 286. 
A. Anafarta - N. Kaya 13/3 (2021) 2523-2536

Wu, Y. \& Geng, S. (2014). Evaluation of coal supplier based on intuitionistic fuzzy set and VIKOR method. Journal of Information \& Computational Science, 11(11), 3753-3763.

Yilmaz, E. (2012). Integrated fuzzy AHP-VIKOR method for supplier selection. Marmara University Journal of Economic and Administrative Sciences, 33(2), 331-354.

You, X-Y. You, J-X., Liu, H-C. \& Zhen, L. (2015). Group multi-criteria supplier selection using an extended VIKOR method with interval 2-tuple linguistic information. Expert Systems with Applications, 42, 1906-1916.

Yücenur, G. N. \& Demirel, N. Ç. (2012). Group decision making process for insurance company selection problem with extended VIKOR method under fuzzy environment. Expert Systems with Applications, 39, 3702-3707.

Zhou, X. \& Xu, Z. (2017). An integrated decision making model for sustainable supplier selection under uncertain environment. International Conference on Industrial Engineering and Engineering Management, Singapore, 10-13 December 2017, IEEE, 1536-1540. 